\title{
TOWARDS A NEW COMPREHENSIVE PARTNERSHIP - ECONOMIC AND TRADE RELATIONS BETWEEN THE GULF COOPERATION COUNCIL AND THE EUROPEAN UNION
}

\begin{abstract}
ADRIANA KALICKA-MIKOLAJCZYK*
"I believe that we should reinforce our cooperation in the fields of mutual interests: industry, energy, research and education, science and technology, information and communications technology, investment and climate actions. An exchange of information and knowledge but also of culture will be of mutual benefit for our both regions. We have so much in common and still a lot we can learn from each other!"1
\end{abstract}

\section{INTRODUCTION}

The Gulf Cooperation Council was established in 1981 by six countries of the Arabian Peninsula. The Charter establishing the first regional cooperation organisation was signed on 25 May 1981 in Abu Dhabi by Bahrain, Kuwait, Oman, Qatar, Saudi Arabia and the United Arab Emirates. The preamble contains all the reasons which led to establishing this form of cooperation between these neighbouring countries, "the Member States are desiring to effect coordination, cooperation and integration between them in all fields and they have the conviction that coordination, cooperation, and integration between them serve the sublime objectives of the Arab Nation".2.

DOI: $10.1515 /$ wrlae-2015-0033

* PhD in Law, Assistant Professor, University of Wroclaw, Faculty of Law, Administrartion and Economics, Department of International and European Law; adriana.kalickamikolajczyk@uwr.edu.pl

1 Angelika Niebler, Member of the European Parliament and Chair of the European Parliament Delegation for Relations with the Arab Peninsula $<$ http://www.eurochambres.eu/custom/19-EU GulfCC Invest Trade conference 9Apr142014-00271-01.pdf. $>$ accessed 7 October 2014.

${ }^{2}$ The Cooperation Council for the Arab States of the Gulf- Secretariat General, 'The Charter' $<$ http://www.gcc-sg.org/eng/indexfc7a.html?action=Sec-Show\&ID=1> accessed 7 October 2014; Bichara Khader, 'EU, GCC and the Arab Spring: time for a strategic partnership?' [2013] $2<$ http://acimedit.net/wp-content/uploads/2013/04/EU-GCC-AND-THE-ARABSPRING-TIME-FOR-A-STRATEGIC-PARTNERSHIP1> accessed 7 October 2014. 
Soon after the formation, the Gulf Cooperation Council took the initiative to launch the cooperation with the European Community in order to establish close relationship in economic and trade areas. As a result of these steps, both organisations signed on 15 June 1988 the Cooperation Agreement, which still remains the legal framework for EU-GCC relations. Both Parties are committed to negotiations towards a Free Trade Agreement to establish a free trade area between them. Such negotiations were initiated in 1991. However in 2008, due to the absence of any progress, the GCC unilaterally suspended negotiations talks, but approved the EU demand to continue consultations between them, until a common position for resuming negotiations is achieved.

The aim of this paper is twofold: 1) to present a retrospective of the analysis of the economic and trade relations between the European Community/European Union and the Gulf Cooperation Council (GCC) since 1981 and 2) to analyse the prospects for the possibility to renovate, to foster and deepen economic and trade relations between these two international organisations in the nearest future in the form of the Free Trade Area. Because of these two general objectives of this paper, the following two research methods were used: 1) analytical-legal and 2) dogmatic-legal.

\section{The Gulf Cooperation Council}

The overall objectives of the GCC are: 1) to effect coordination, integration and inter-connection between Member States in all fields in order to achieve unity between them; 2) to deepen and strengthen relations, links and areas of cooperation now prevailing between their peoples in various fields; 3) to formulate similar regulations in various fields including the following: economic and financial affairs; commerce, customs and communications; education and culture; 4) to stimulate scientific and technological progress in the fields of industry, mining, agriculture, water and animal resources; 5) to establish scientific research; 6) to establish joint ventures and encourage cooperation by the private sector for the good of their peoples ${ }^{3}$.

However, there is also one more very important objective which is not mentioned in art. 4 which is to ensure the collective security of the region by promoting military cooperation between the member States. A Joint GCC Defence Agreement was concluded on 10 December 2001, providing for collective self-defence, and a common defence force numbering 7,000 troops, called the Al-Jazeerah Shield Joint Forces, which in December 2013 became the unified land command under the Unified Military Command of the GCC, and its name was changed to "Command of Al-Jazeerah Shield Forces"4. More recently, the Member States have decided to put the emphasis on cooperation in the area of security which led to the signing of a GCC CounterTerrorism Agreement in 2004 and in 2006 a Permanent Anti-Terrorism

\footnotetext{
${ }^{3}$ Art. 4 of the Charter.

4 The Cooperation Council for the Arab States of the Gulf- Secretariat General, 'Joint Military Action' < https:/www.gcc-sg.org/eng/index8409.html?action=Sec-Show\&ID=49> accessed 7 October 2014.
} 
Committee was formed ${ }^{5}$. To enhance cooperation among Member States at times of wars or natural disasters, the Interior Ministers approved in 2008 the Joint Plan of Action to Confront the Cases of Emergency Migration.

\section{ECONOMIC INTEGRATION BETWEEN THE GCC MEMBER STATES}

Economic integration refers to the process of trade cooperation among two or more states which can comprise four stages. This process can began with the formation of a free trade area, which aim is to remove all trade barriers between the member states ${ }^{6}$. The second stage of economic integration is a customs union, where all member states agree to delete all internal trade barriers between them plus agree to unify their external tariff and to introduce one Common External Tariff (CET), which means that they establish the same trade barriers on the same categories of products in the harmonised system of customs laws and procedures ${ }^{7}$. The third stage is a common market where the member states agree to guarantee the four freedoms: free movement of people, goods, services and capital. The fourth stage is an economic and monetary union where member states agree to coordinate their economic and fiscal policies, to establish a common monetary policy and to introduce a common currency ${ }^{8}$.

The demands of the globalisation process and increasing economic pressures have persuaded many countries from different regions to start cooperation within the regional trade organisations and the Charter of the establishment the GCC is very good example in this case ${ }^{9}$. It states in Article 4 that economic and financial coordination, integration and inter-connection between Member States in order to achieve unity between them is the basic objective of the GCC.

In 1983, the GCC free trade area was established and two freedoms were introduced: the free movement of goods and the free movement of people. In 2003, it evolved into a customs union with the adoption of a CET; however, since 2008 it is a common market. Nowadays, Member States work together towards the introduction an economic and monetary union- a single common market with a common currency- much like the European Union ${ }^{10}$.

The specific objectives of economic cooperation are outlined in the Economic Agreement between the GCC Member States, concluded on 31 December 2001, aims: to establish closer ties and stronger links among

\footnotetext{
5 The Cooperation Council for the Arab States of the Gulf- Secretariat General, 'Security Cooperation' $\quad<$ http://www.gcc-sg.org/eng/index142e.html?action=Sec-Show\&ID=50> accessed 7 October 2014.

${ }^{6}$ Raj Bhala, International Trade Law: Interdisciplinary Theory and Practice ( New York, LexisNexis 2008).

7 ibid 26.

${ }^{8}$ Oker Gürler, 'Role and Function of regional Blocs and Arrangements in the Formation of the Islamic Common Market' (2000) 21(4) Journal of Economic Cooperation 1.

${ }^{9}$ Gonzalo Villalta Puig, Bader Al-Haddab, The Constitutionalisation of Free Trade in the Gulf Cooperation Council' (2011) 25 Arab Law Quarterly 314.

${ }^{10}$ ibid 315.
} 
Member States; to enhance economic relations among them, and to unify national policies with respect to economic, financial and monetary affairs and to strengthen their negotiating position and competitive capacity in international markets ${ }^{11}$. The Economic Agreement consists of nine chapters and thirty three articles which focus on ${ }^{12}$ :

1. the establishment of the GCC Customs Union;

2. the international economic relations between Member States and the other countries, economic groupings and international and regional organizations, and the provision of international and regional aids;

3. the establishment of the GCC Common Market which specifies the areas of the Economic Nationality;

4. the establishment of the Monetary and Economic Union;

5. improving the investment climate in Member States;

6. the development of integration across Member States, including industrial development, development of oil and gas and the natural resources, agricultural development, environment preservation and joint projects;

7. development of human resources, including education, the eradication of illiteracy, compulsion for a basic education, activation of the population strategy, nationalizing and training of the labour force and increasing their contribution to the labour market;

8. scientific and technical research, development of scientific, technological and informatics database and the protection of intellectual property rights and

9. integration in the infrastructure areas, including transportation, telecommunications and e-commerce.

In addition, the Economic Agreement contains in Chapter 8 mechanisms for implementation, follow-ups and dispute settlement. Article 27 provides for the formation of a judicial commission to adjudicate disputes arising from the implementation of the Agreement and the resolutions for its implementation.

The GCC States have established a Free Trade Area (FTA) in March 1983 which lasted for almost twenty years, until the end of 2002. Throughout the FTA between 1983 and 2002, the volume of Intra-GCC trade increased from less than US\$ 6 billion in 1983 to some US\$ 20 billion in $2002^{13}$. On 1 January 2003 FTA was transformed into a Customs Union. According to the provisions of the Article 1, trade between the GCC Member States is conducted within the framework of a Customs Union, which includes: 1) common external customs tariff (CET); 2) common customs regulations and procedures; 3) single entry point where customs duties are collected; 4) elimination of all tariff and non-tariff barriers, while taking into consideration laws of agricultural and veterinarian quarantine, as well as rules regarding prohibited and restricted goods; 5) goods produced in any Member State

11 The Cooperation Council for the Arab States of the Gulf- Secretariat General $<$ http://sites.gcc-sg.org/DLibrary/index-eng.php?action=ShowOne\&BID=168> accessed 10 October 2014.

${ }^{12}$ The Cooperation Council for the Arab States of the Gulf- Secretariat General, 'The Economic Agreement 2001'< http://www.gcc-sg.org/eng/indexe89c.html?action=SecShow \&ID=396> accessed 10 October 2014 .

13 Neil Patrick, 'The GCC: Gulf state integration or leadership cooperation?' $3<$ http://eprints.lse.ac.uk/55660/> accessed 12 October 2014. 
should be accorded the same treatment as national products ${ }^{14}$. On 1 January 2002 the Common Customs Law was implemented by all of the GCC Member States and next, on 1 January 2003, Member States achieved an important step by establishing the Customs Union where a common tariff of $5 \%$ was levied on all foreign imports ${ }^{15}$. Customs procedures are applied to all foreign goods at the first point of entry into any of the GCC Member States. The first entry point carries out all the procedures of inspection and investigation, and ensures compliance with the required documents, and that they are lawful, and it subsequently levies the duties applicable to them ${ }^{16}$. The intra-GCC movement of national and foreign goods has achieved a considerable growth since establishing the Customs Union in January 2003. Intra-GCC trade reached 124.7 billion US dollars in 2013, compared to 15 billion US dollars in $2002^{17}$.

In 2007, the GCC Supreme Council took the decision to launch a Common Market between the Member States within the GCC. Article 3 obliges each Member State to accord other Member States' natural or legal citizens the same treatment in respect of all economic activities without differentiation or discrimination, which includes: free movement and the right of residence; right to work in private and government jobs; pension and social security; right to be engaged in all professions and crafts; right to be engaged in all economic, investment and service activities; right to real estate ownership; free capital movement; equal tax treatment; right to stock ownership; the formation of corporations and education, health and social services $^{18}$. The Common Market thus endows GCC citizens with equal treatment in respect of all economic activities, which means that GCC natural or legal citizens enjoy national treatment in each Member State ${ }^{19}$. So, the fundamental principle of the GCC Common Market is the concept of Gulf Economic Nationality, which refers to the individual right to equal treatment in respect of any economic activity in the GCC common market ${ }^{20}$. Article 8 of the initial Economic Agreement adopted in November 1981 mentions only four areas: 1) freedom of movement, work and residence; 2) the right of ownership, inheritance and will; 3 ) the freedom of engagement in economic activity and 4) free movement of capital. However, during the first two decades of establishing the GCC, the concept of equal treatment among GCC

\footnotetext{
${ }^{14}$ Art. 1 Economic Agreement.

${ }^{15}$ The Cooperation Council for the Arab States of the Gulf- Secretariat General, 'The Free Trade Area'

$<$ http://www.gcc-sg.org/eng/index1856.html?action=Sec-Show\&ID=413> accessed 12 October 2014.

${ }^{16}$ The Cooperation Council for the Arab States of the Gulf- Secretariat General, 'The GCC Customs Union - January 2003' < http://www.gcc-sg.org/eng/index 81c2.html?action=SecShow\&ID=414> accessed 12 October 2014.

17 The Cooperation Council for the Arab States of the Gulf- Secretariat General, 'Achievements' <http://www.gcc-sg.org/eng/index39a7.html?action=Sec-Show\&ID=412> accessed 12 October 2014.

${ }^{18}$ Art. 2 Economic Agreement.

19 Vilallta Puig, Al-Haddab (n 9) 317.

${ }^{20}$ ibid 318.
} 
nationals was developed to many areas of the Agreement ${ }^{21}$. In order to move from the stage of coordination and cooperation to integration, the trend adopted by the Economic Agreement 2001 tends to the direct application of the concept of fully equal treatment in all economic fields ${ }^{22}$. Article 3 of the Economic Agreement (2001) provides for direct implementation of the concept of fully equal treatment for all GCC nationals through according GCC nationals residing in any Member State the same treatment accorded to its nationals without differentiation or discrimination in all economic fields; this includes natural and legal nationals. The resolution adopted by the Supreme Council at its 23rd session in December 2002, identified a time schedule for the completion of the requirements of the GCC Common Market, as follows ${ }^{23}$ :

1) equal treatment shall be accorded to the GCC citizens by 2003 in the field of employment in the private sector, stock ownership, formation of corporations and elimination of relevant barriers;

2) equal treatment shall be accorded to the GCC citizens by 2005 in the field of government jobs, social insurance and pension and elimination of relevant barriers;

3) competent committees shall complete all requirements to ensure achievement of the GCC Common Market by 2007 at the latest.

Under the Common Market the GCC Member States adopted the principle of equal treatment accorded to citizens by 2003 in various fields, such as engagement in retail and trade, stock ownership, formation of joint ventures, encouragement of mutual investment and the elimination of barriers to intra-GCC trade. In addition, the GCC Member States have adopted a Unified Trade Policy vis-à-vis other countries, the World Trade Organization and other international and regional organizations as a single economic entity with a view to promote trade and investment, expand markets, increase GCC exports, and their competitive capacity ${ }^{24}$. Moreover, the GCC Unified Trade Policy also aims at adopting an internal unified trade policy, which facilitates the movement of GCC citizens, goods, services, and means of transportation.

Chapter III of the Economic Agreement governs the Economic and Monetary Union, which is one of the main aims of the cooperation between the Member States within the GCC. According to the provisions of the Article 4 currency unification and monetary union are going to be introduced according to a specified timetable and to achieved through a high level of harmonization in all economic policies, especially fiscal and monetary policies, banking legislation, setting criteria as to approximate rates of economic performance related to fiscal and monetary stability, such as rates of budgetary deficit, indebtedness, and price levels. The Supreme Council on

\footnotetext{
21 ibid.

${ }^{22}$ The Cooperation Council for the Arab States of the Gulf- Secretariat General, 'The GCC Economic nationality' < http://www.gcc-sg.org/eng/index39e0.html?action=SecShow \&ID $=429>$ accessed 12 October 2014.

${ }^{23}$ ibid.

${ }^{24}$ The Cooperation Council for the Arab States of the Gulf- Secretariat General, 'Cooperation in Trade' <http:/www.gcc-sg.org/eng/index322b.html?action=Sec-Show\&ID=409> accessed 15 October 2015.
} 
its 26th session in December 2005 approved the following criteria for achieving economic convergence and financial and monetary stability ${ }^{25}$ :

1) monetary convergence criteria: these constitute inflation rates, interest rates and the sufficiency of the foreign cash reserves;

2) financial convergence criteria: these constitute the annual deficit ratio of government finance to GNP and the ratio of public debt to GNP.

Next, the Supreme Council on its 29th session in December 2008 approved the Monetary Union Agreement (MAU) that laid down the legal and institutional framework of the Monetary Union. The MUA has specified the tasks of the Monetary Council and the GCC Central Bank, which will issue the single currency. At this session, the Supreme Council also approved the Statute of the Monetary Council and instructed the Member States to ratify the Agreement at the earliest time in order to prepare for establishing the Monetary Council and enable it to carry out its tasks by 2009 at the latest. In May 2009, the Supreme Council approved the city of Riyadh as the location of the Monetary Board. In addition, on June 7, 2009 Member States signed the Monetary Union Agreement ${ }^{26}$. According to the provisions of the Article 3, establishing the Monetary Union shall entail: 1) coordination of the economic policies of Member States to ensure that they are conducive to fiscal and monetary stability; 2) settlement systems necessary for introducing the single currency; 3 ) adoption of uniform banking legislation and common rules in the field of banking supervision; 4) establishment of a monetary council which will prepare for the establishment of a Central Bank as an independent institution that will draw up and implement the monetary policy and the exchange rate policy of the single currency area; 5) introduction of a single currency which shall substitute the currencies of Member States ${ }^{27}$.

In the Long-term Comprehensive Development Strategy adopted by the Supreme Council at its 29th session in Muscat on 29-30 December 2008, the Member States assessed the challenges facing the GCC in the various spheres such as: sustainable development, security and defence issues, economic issues, issues related to technical and scientific capacity, issues of regional and international economic relations, social issues, population and manpower issues and issues related to media ${ }^{28}$. This document contains a brief review and exposition of the achievements of the GCC States in terms of development, which were made collectively. This main goal for this development plan is "accomplishing sustainable and integrated development for the GCC states, effecting coordination between the activities of the national development plans, imparting the necessary flexibility to serve the

\footnotetext{
${ }^{25}$ The Cooperation Council for the Arab States of the Gulf- Secretariat General, 'The Monetary Union and the Single Currency' < http://www.gccsg.org/eng/indexeeff.html?action=Sec-Show\&ID=58> accessed 15 October 2015.

${ }^{26}$ ibid.

27 The Cooperation Council for the Arab States of the Gulf- Secretariat General, 'GCC Monetary Union Agreement' $6 \quad<$ http://sites.gcc-sg.org/DLibrary/indexeng.php?action=ShowOne\&BID=321 $>$ accessed 15 October 2015 .

${ }^{28}$ The Cooperation Council for the Arab States of the Gulf- Secretariat General, 'Long Term Comprehensive Development Strategy for the GCC States'< $\underline{\text { http://sites.gcc- }}$ sg.org/DLibrary/index-eng.php?action=ShowOne\&BID=169> accessed 18 October 2015.
} 
goals of development in each state separately and jointly at the level of the Council, thereby accomplishing a constant rise in the quality of life of the people in the GCC states and instilling the capacity to adjust with the developments of the 21 st century" ${ }^{29}$. According to this document, the Member States "should take stock of all the available opportunities and limitations imposed upon them as well as the challenges facing them, so that it could build new paths towards a future, which is in harmony with the hopes and aspirations of its people, and which looks forward to a better tomorrow for their future generations. It is a matter that entails learning the useful lessons from the achievements of the development process and its failures in each and every GCC state. This should be done in order to evolve better paths of development so as to facilitate the movement towards the goals and objectives laid down for the early decades of the 21 st century" 30 . Among the challenges facing the GCC Member States are economic issues and issues related to regional and international economic relations. The strategic objective of the regional and international economic relations is "to enhance the GCC economic integration objectives represented in broadening and deepening the market, increasing efficiency in the local economies and strengthening their capacity to negotiate and to compete in the foreign markets" 31 . This objective can be achieved by adopting the following approaches: 1) deepening the bonds of cooperation with the Arab and Islamic countries; 2) coordinating the import-export policies from and to the international markets as well as pursuing the policy of transfer of technology from these markets; 3 ) increasing export industries and ensuring an increasing share of the GCC States in the conventional markets of their trading partners; 4) developing and harmonizing trade and investment laws; 5) organizing more joint exhibitions and encouraging establishment of export promoting companies; 6) establishing economic partnerships between the GCC States and the other world countries and economic groupings ${ }^{32}$.

\section{The Gulf Cooperation Council AND THE European UNION}

"A deeper relationship also means an open one and means honest discussions on issues where we may of course have different perspectives. We did that today, and we will continue to do that in the future" 33 .

The relationship between the European Union (EU) and the GCC is governed by a Cooperation Agreement (CA) signed on 15 June $1988^{34}$ as well

\footnotetext{
29 ibid 3.

30 ibid 2.

${ }^{31}$ ibid 5-6.

32 ibid 6.

${ }^{33}$ European Union, 'Remarks by High Representative Catherine Ashton following the $22^{\text {nd }}$ EU-GCC Joint Council and Ministerial Meeting 25 June 2012 Luxembourg < http://eeas.europa.eu/gulf cooperation/news/index en .htm $>$ accessed 18 October 2015.

${ }^{34}$ Cooperation Agreement between the European Economic Community, of the one part, and the countries parties to the Charter of the Cooperation Council for the Arab States of the Gulf (the State of the United Arab Emirates, the State of Bahrain, the Kingdom of Saudi Arabia,
} 
as a Joint Action Programme agreed on 14th June $2010^{35}$. Both Parties are committed to negotiations towards a Free Trade Agreement which were initiated in $1990^{36}$. The overall objective of the CA is to contribute towards strengthening stability in a region and to facilitate political, trade and economic relations with its Partner. According to the provisions of the Article 1 it aims: (a) to strengthen relations between Parties by placing them in an institutional and contractual framework; (b) to broaden and consolidate their economic and technical cooperation relationship and also cooperation in energy, industry, trade and services, agriculture, fisheries, investment, science, technology and the environment, on mutually advantageous terms, taking into account the differences in levels of development of the Parties and (c) to help strengthen the process of economic development and diversification of the GCC countries and so reinforce the role of the GCC in contributing to peace and stability in the region. However, the CA is not a long international agreement because it consists of 26 articles divided into three parts: 1) general objectives (art.1); 2) economic cooperation (art. 2-11) and 3) general final provisions (art. 12-26), which show us that the most important areas of the cooperation are trade and economy. Economic cooperation should be as extensive as possible, not excluding any area of common interest. Here, and in the technical area, the priorities are to encourage and facilitate: a) diversification of GCC countries' structures of their economies; b) market research and trade promotion; c) technology transfer and development, notably by means of joint ventures between undertakings and institutions in these two regions and the protection of patents, trademarks and intellectual property rights; d) the promotion of stable and balanced links between traders; e) cooperation on standards and measures; f) information exchange and g) training ${ }^{37}$. In areas of agriculture and fisheries, the aims of cooperation are: to step up exchanges of information and to encourage contacts between companies and research institutions to promote common projects ${ }^{38}$. In industry, the aim is to encourage joint enterprises, develop industrial production and enlarge the economic base, and to organise contacts and meetings ${ }^{39}$. For energy, cooperation between energy companies must be facilitated, as must joint analyses of trade in crude oil, gas and petrol products. Exchanging ideas and information, training and studies are also part of energy cooperation ${ }^{40}$. Investment must be promoted and

\footnotetext{
the Sultanate of Oman, the State of Qatar and the State of Kuwait) of the other part - Joint Declarations - Declaration by the European Economic Community - Exchange of Letters [1989] OJ L 54.

35 Joint Action Programme for Implementation of the GCC-EU Cooperation Agreement of $1988<\underline{\text { http://eeas.europa.eu/gulf cooperation/docs/joint action programme en.pdf }>}$ accessed 18 October 2015.

36 Ana Echagüe, 'The European Union and the Gulf Cooperation Council < http://fride.org/download/WP39 EU Persian Gulf EN may07.pdf $>$ accessed 18 October 2015; The EU and the GCC - A New Partnership, European University Institute, Florence 2002, http://www.iue.it/RSCAS/WP-Texts/02 07p.pdf, accessed 15 June 2013.

${ }^{37}$ Art. 2 of the CA.

${ }^{38}$ Art. 4 of the CA.

${ }^{39}$ Art. 5 of the CA

${ }^{40}$ Art. 6 of the CA
} 
protected, particularly through agreements on promotion and protection to improve investment conditions. Trade should be developed and diversified. The Parties agreed to: study ways of eliminating trade barriers; open discussions on an agreement aimed at developing trade and grant each other the status of most favoured nation ${ }^{41}$.

A Joint Cooperation Council was set up which is composed of representatives of the EU, on the one hand, and of representatives of the GCC Member States, on the other. It has a competence to lay down the general guidelines for cooperation, to act as an arbiter in the event of dispute and to seek means of putting cooperation into practice ${ }^{42}$. The Joint Council may formulate any resolutions, recommendations or opinions which it considers desirable for the attainment of the common objectives. Its decisions are binding on the Parties, and its presidency is rotated between the EC and the GCC. It is assisted by a Joint Cooperation Committee, and may decide to set up further committees ${ }^{43}$. The CA provides for annual Joint Council meetings between the EU and the GCC foreign ministers, and for Joint Cooperation Committees at senior officials' level. The most recent EU-GCC ministerial meeting took place in Manama, Bahrain on 30 June 2013, co-chaired by the EU High Representative-Vice President Ashton and the Bahraini Foreign Minister. The meeting covered a number of discussions on a range of topics including joint economic growth and trade between the EU and Gulf states. The Ministers expressed support for the ongoing diplomatic efforts of the EU High Representative to seek a diplomatic solution to the Iranian nuclear issue; welcomed the current efforts of US Secretary of State to reinvigorate the Middle East Peace Process, reaffirmed their shared position on that issue; underlined the importance of a unified international stance to reach a comprehensive political solution to put an end to the Syrian crisis ${ }^{44}$. Catherine Ashton stated:

"Our attention is still very much focused on Syria. We believe that we need to work hard together to find the political solution that will bring peace. We are extremely concerned about the plight of the people, and about the rising sectarian conflicts in Lebanon and Iraq, and we want to do our utmost to try and defuse tension" 45 .

Both Parties have agreed to exchange information and consult the Joint Council regarding useful information that has a direct incidence on the CA; possible problems in the general functioning of the CA or concerning trade ${ }^{46}$. Any dispute which may arise between the EU and the GCC concerning the interpretation of the CA is placed before the Joint Council. If fails to settle the dispute at its next meeting, either Party may notify the other of the appointment of an arbitrator; the other Party must then appoint a second arbitrator within two months. The Joint Council shall appoint a third arbitrator. The decisions of the arbitrators are taken by majority vote. Each Party must take all measures required for the implementation of the

\footnotetext{
${ }^{41}$ Art. 11 of the CA

${ }^{42}$ Art. 12 of the CA

${ }^{43}$ Art. 15 of the CA.

${ }^{44}$ Joint Council and Ministerial Meeting of the Cooperation Council for the Arab States of the Gulf (GCC) $\quad<$ http://eeas.europa.eu/top stories/2013/010713 eugcc joint council en.htm $>$ accessed 19 October 2015. 
arbitrators' decision $^{47}$. The CA does not prevent the conclusion of bilateral agreements, providing that they do not conflict with this agreement. Its duration is unlimited, and if one party renounces it in writing, its application will cease six months after the notification date ${ }^{48}$.

On 22 November 1995, the European Commission adopted the Communication entitled "Improving relations between the European Union and Countries of the Gulf Cooperation Council"49. In this document the European Commission reiterates the recommendations made at the Troika Ministerial meeting in Granada on 20 July 1995 to boost relations between the EU and the GCC. These recommendations include: 1) strengthening the political dialogue; 2) increasing economic cooperation and unblocking the ongoing free trade negotiations and 3) developing instruments of cultural and scientific cooperation to promote increased reciprocal knowledge ${ }^{50}$. The European Commission concludes by recommending that the Council should: reaffirm the strategic importance of a strong GCC; reaffirm its commitment to the development of strong and mutual relations; confirm the need to include the GCC countries in the EU's global strategy for improving relations with partners from other regions; reaffirm its desire to achieve a qualitative improvement in these relations and reinforce EU-GCC political cooperation at ministerial level ${ }^{51}$.

The joint GCC-EU Ministerial Council, at its 20th session held in Luxemburg on 14th June 2010, adopted a Joint Action Programme for Implementation of the GCC- EU Cooperation Agreement 2010-2013, setting out a roadmap for closer cooperation on fourteen issues such as trade, nuclear safety, clean energy, research, and economic dialogue, and are currently engaging on a new document guiding cooperation between the EU and the $\mathrm{GCC}^{52}$. Provisions of this document are implemented through regular expert meetings and specialized workshops.

Table 1: Areas of cooperation between Parties on the basis of a Joint Action Programme for Implementation of the GCC- EU Cooperation Agreement 2010-2013.

\begin{tabular}{|l|l|}
\hline Subject & Areas of Cooperation \\
\hline $\begin{array}{l}\text { Economic, Financial } \\
\text { and Monetary }\end{array}$ & $\begin{array}{l}\text { Continued exchange of views on macroeconomic } \\
\text { issues; Exchange of expertise and information in } \\
\text { Cooperation }\end{array}$ \\
all aspects of the GCC \& EU experience in \\
\hline
\end{tabular}

\footnotetext{
47 Art. 21 of the CA.

48 Art. 23 of the CA

${ }^{49}$ Communication from the Commission to the Council, Improving relations between the European Union and Countries of the Gulf Cooperation Council [1995] COM 541 final.

${ }^{50}$ ibid 3-4; Asa Trulsson, 'The EU's interregional relationship with the GCC- an assessment of the current cooperation, $<$ https://ba.linkedin.com/pub/\%C3\%A5sa-trulsson/33/a08/ab8 $>$ accessed 18 October 2015.

51 ibid 11 .

52 Joint Action Programme for Implementation of the GCC-EU Cooperation Agreement of $1988<\underline{\text { http://eeas.europa.eu/gulf cooperation/docs/joint action programme en.pdf }>}$ accessed 18 October 2015.
} 


\begin{tabular}{|c|c|}
\hline & $\begin{array}{l}\text { economic integration; Technical cooperation in } \\
\text { specific topics to be agreed upon in economic, } \\
\text { financial and monetary areas; Continued } \\
\text { cooperation with the EU Central Bank in the area } \\
\text { of the GCC Monetary Union. }\end{array}$ \\
\hline Investment & $\begin{array}{l}\text { Encouragement of mutual investment; } \\
\text { Development of small and } \\
\text { medium enterprises in the GCC States; } \\
\text { Development of GCC human resources in various } \\
\text { production activities and latest technologies }\end{array}$ \\
\hline Trade cooperation & $\begin{array}{l}\text { Enhance trade relations in order to increase } \\
\text { bilateral GCC-EU trade }\end{array}$ \\
\hline Energy & $\begin{array}{l}\text { Exchange views on oil and gas market } \\
\text { developments as well as the energy policies on } \\
\text { both Sides; Exchange information and } \\
\text { experiences on policies, frameworks, best } \\
\text { practices and techniques in the field of energy, in } \\
\text { upstream, midstream, and downstream } \\
\text { (infrastructure); Cooperation in the field of energy } \\
\text { equipment, machinery and spare parts } \\
\text { manufacturing especially those used in the oil and } \\
\text { gas industry. } \\
\text { Cooperation in the field of clean and renewable } \\
\text { energy technologies. } \\
\text { Cooperation in the field of energy efficiency } \\
\text { policy and measures. } \\
\text { Cooperation in the field of solar energy } \\
\text { technologies and policy framework. }\end{array}$ \\
\hline Electricity \& Water & $\begin{array}{l}\text { Technical cooperation in all stages of electricity } \\
\text { and water } \\
\text { production (generation, transport, energy transfer } \\
\text { distribution and service providers), including } \\
\text { technology transfer; Benefit from the EU in: } \\
\text { power interconnection, load management, } \\
\text { regulatory } \\
\text { framework and in creating and developing } \\
\text { regional markets for } \\
\text { the trade in, and exchange of, electricity. } \\
\text { Exchange of best practices in RDT (Research, } \\
\text { Development and Technology) regarding the } \\
\text { integrated management and sustainable } \\
\text { development of water, in order to achieve water } \\
\text { security in the GCC states. Exchange best } \\
\text { practices and techniques in the efficient use of } \\
\text { power and water consumption. }\end{array}$ \\
\hline Nuclear Safety & $\begin{array}{l}\text { Cooperation in the field of atomic energy as well } \\
\text { as nuclear safety and security. Exchange of } \\
\text { information and experience in matters such as the } \\
\text { legal framework for protection against radiation, }\end{array}$ \\
\hline
\end{tabular}




\begin{tabular}{|c|c|}
\hline & $\begin{array}{l}\text { nuclear security and safety, radioactive waste, } \\
\text { warranties } \\
\text { and appropriate systems and surveillance. }\end{array}$ \\
\hline Transport & $\begin{array}{l}\text { Cooperation in the field of development, } \\
\text { construction operation and maintenance of } \\
\text { railway projects in GCC States. Cooperation in } \\
\text { maritime affairs: passengers, vessel inspection, } \\
\text { maritime legislation, safety regulations and } \\
\text { navigation security. Benefit from the EU } \\
\text { experience in the aviation management as well as } \\
\text { areas of studies and scientific research in various } \\
\text { aviation areas, particularly } \\
\text { aviation and air transport safety and security. } \\
\text { Exchange of expertise in formulating work } \\
\text { policies and procedures related to the } \\
\text { issuing of landing and transit permits for all types } \\
\text { of aircraft. Benefit from the EU experience } \\
\text { regarding professional road } \\
\text { transport and road safety for all road users. In } \\
\text { terms of professional road transport: the emphasis } \\
\text { should be placed on fair competition, rights of } \\
\text { drivers, passengers, students and workers; this } \\
\text { would } \\
\text { include rules on the access to the profession and } \\
\text { social rules } \\
\text { for drivers. }\end{array}$ \\
\hline $\begin{array}{ll}\text { Environment } & \& \\
\text { climate change } & \end{array}$ & $\begin{array}{l}\text { Cooperation in the field of waste recycling, related } \\
\text { power generation technologies and building } \\
\text { indigenous technologies in these fields, as well as } \\
\text { exchange of expertise and research and } \\
\text { cooperation between industries and research } \\
\text { centres. Exchange views and studies on the causes } \\
\text { and effects of climate change as well as policies } \\
\text { dealing with climate change within the framework } \\
\text { of relevant UN conventions. 3. Cooperation in } \\
\text { developing national adaptation strategies to } \\
\text { climate change impact. Enhance cooperation in } \\
\text { the field of carbon capture and storage; and } \\
\text { conduct joint studies in this connection. Enhance } \\
\text { technical cooperation } \\
\text { and exchange of studies as well as researches in } \\
\text { the field of the environmental impact related to the } \\
\text { handling and use of chemicals, such as import, } \\
\text { export, production, manufacturing, sale, } \\
\text { transportation and storage. Cooperation in the } \\
\text { field of disaster management and environmental } \\
\text { crises. Cooperation in the field of water }\end{array}$ \\
\hline
\end{tabular}




\begin{tabular}{|c|c|}
\hline & $\begin{array}{l}\text { management and combating desertification. } \\
\text { Cooperation in the field of preservation of } \\
\text { biodiversity. Cooperation in the field of } \\
\text { environmental aspects of water and waste water } \\
\text { treatment. }\end{array}$ \\
\hline Industry & $\begin{array}{l}\text { Support efforts of the GCC States in the } \\
\text { development of their industrial production and } \\
\text { diversification of their industrial base, taking into } \\
\text { account the mutual interests of both parties. } \\
\text { Benefit from the available EU programmes and } \\
\text { mechanisms in the development and the updates } \\
\text { of the GCC industrial structure, as well as } \\
\text { increasing the competitive capacities of } \\
\text { production sectors. Encourage and attract } \\
\text { investment and set up joint projects. Cooperate in } \\
\text { the preparation of studies, consultation, and the } \\
\text { joint industrial statistical surveys }\end{array}$ \\
\hline $\begin{array}{l}\text { Combating money } \\
\text { laundering and } \\
\text { terrorist financing }\end{array}$ & $\begin{array}{l}\text { Enhance cooperation in the field of combating } \\
\text { money laundering and terrorist financing. }\end{array}$ \\
\hline $\begin{array}{l}\text { Intellectual } \\
\text { Property rights }\end{array}$ & Intellectual property rights and patenting \\
\hline $\begin{array}{l}\text { Telecommunications } \\
\text { and Information } \\
\text { Technology } \\
\text { Sector }\end{array}$ & $\begin{array}{l}\text { Exchange expertise and information in the field of } \\
\text { regulating telecommunications and Internet } \\
\text { governance. } \\
\text { Exchange expertise in the field of E-commerce } \\
\text { applications } \\
\text { and E-transactions and benefit from IT training } \\
\text { programmes. }\end{array}$ \\
\hline $\begin{array}{l}\text { Higher } \\
\text { Education and } \\
\text { Scientific } \\
\text { Research }\end{array}$ & $\begin{array}{l}\text { Enhance GCC participation in ERASMUS } \\
\text { MUNDUS and } \\
\text { Marie Curie Scientific Mobility Programmes. } \\
\text { Establish a sustained } \\
\text { partnership between EU and GCC universities for } \\
\text { cooperation in teaching Arabic language and } \\
\text { Middle Eastern studies. Establish and develop } \\
\text { joint supervision programmes between GCC and } \\
\text { EU universities through which scholarships would } \\
\text { be granted to students of GCC universities to } \\
\text { study in the EU in major fields that are important } \\
\text { to the GCC States. Cooperation with EU } \\
\text { universities in developing academic programmes } \\
\text { at GCC universities, focusing on new scientific } \\
\text { specializations such as the peaceful use of nuclear } \\
\text { energy, genetics, etc. Open up the field for GCC } \\
\text { universities and Research Centres to make use of } \\
\text { the INCONET initiative for scientific research. } \\
\text { Transfer of the EU expertise in the field of } \\
\text { establishing financing and managing research } \\
\text { programmes to the GCC universities and national }\end{array}$ \\
\hline
\end{tabular}




\begin{tabular}{|l|l|}
\hline Tourism & $\begin{array}{l}\text { research centres, and establish a long-term } \\
\text { relationship to foster those practices in research } \\
\text { area. }\end{array}$ \\
\hline $\begin{array}{l}\text { Culture and } \\
\text { mutual } \\
\text { understanding }\end{array}$ & $\begin{array}{l}\text { Discuss possibilities of cooperation in tourism and } \\
\text { joint projects that can be established in this area. }\end{array}$ \\
\hline $\begin{array}{l}\text { Cultural exchange and transfer of the real picture } \\
\text { of GCC culture and acquaint the EU communities } \\
\text { with the artistic and cultural creativity in the GCC } \\
\text { States. Discuss issues of translation } \\
\text { from/to European languages. }\end{array}$ \\
\hline $\begin{array}{l}\text { Antiquities and } \\
\text { Museums }\end{array}$ & To benefit from the EU expertise in this field. \\
\hline
\end{tabular}

Within the framework of the implementation of the provisions of this Program, a number of joint events have been organized in the fields of finance, economy, monetary, trade, industry, investment, energy, nuclear safety, electricity, water, transport, environment, combating money laundering, combating funding terrorism, patent, protection of intellectual property, higher education and scientific research etc. Among these events are the following: 1) joint environment seminar between the GCC and the EU, held in the Sultanate of Oman on 15th and 16th January 2011;2) workshop on commerce and investment, held in Brussels, in October 2012;3) workshop on electricity and water, held in Brussels, in November 2012; 4) a lecture titled "European Union establishments and process of decision-making following execution of the Treaty of Lisbon", held at the headquarters of the GCC Secretariat General, in November 2012, in coordination with the Institute of International Affairs in Rome; 5) workshop on cooperation in research and innovation, held in Brussels, in December 2012; 6) establishment of European Union and GCC network for clean energy; 7) striving to sign Memorandum of Understanding between Eurostat and GCC in the statistical field; 8) a number of GCC Secretariat General officials joined the diplomatic secondment programme at European external relationships body in April 2012, February 2013 and March 2014 ${ }^{53}$.

In the economic field, dialogue is held between the two Parties periodically, the latest of which was the 4th in the series, held in Brussels on 19th March 2013. This dialogue gathered together experts and specialists from both sides to discuss topics of common interest. In addition, periodic meetings were held between governors of monetary agencies and central banks in the GCC States and their counterparts in the European Union ${ }^{54}$. The 3rd meeting was held in June 2012 in Abu Dhabi. Also, a workshop on combating money laundering and terror funding is also held periodically. The 7th workshop was held in November 2011, in Warsaw in Poland ${ }^{55}$.

53 The Cooperation Council for the Arab States of the Gulf- Secretariat General, 'Negotiations with the EU' <https://www.gcc-sg.org/eng/index8efc.html?action=SecShow\&ID=595 $>$ accessed 21 October 2015.

54 ibid.

55 ibid. 
The Joint Cooperation Committee of the GCC and European Union held its 25th meeting in April 2014 at the GCC Secretariat General. The meeting discussed developments in the GCC and the European Union, as well as the work progress in areas of cooperation within the framework of joint cooperation agreement between the GCC and the EU and other areas of cooperation, including existing activities such as trade relations and trade facilitation. In addition, coordination is being made to hold ${ }^{56}$ :

1) 5th economic dialogue in May 2014 at the headquarters of the GCC Secretariat General;

2) A joint seminar between the GCC and the EU in the field of food security, the health of animals, and the importation of food and live animals, during the month of June 2014, at the headquarters of the Secretariat General;

3) Civil Aviation dialogue, during the month of June 2014, in Brussels.

\section{Trade relations between the Gulf Cooperation Council and the European Union}

Since the 1980s European Union exports to the GCC have been increasing. The GCC is the EU's fifth largest export market ( $€ 75$ billion worth of exports in 2011), and the EU is the grouping's biggest trading partner, with trade flows totalling $€ 130$ billion, or $13.5 \%$ of the GCC's global trade ${ }^{57}$. The EU-GCC total trade in goods in 2014 amounted to around $€ 148$ billion (i.e. a very significant increase from $€ 100,6$ billion in 2010) ${ }^{58}$. Moreover, the EUGCC trade grew by 5,8\% on average between 2008 and 2013, it fell by $25,2 \%$ in 2009 and it recovered in 2010 to 2008 levels. Between 2013 and 2014 trade between GCC and EU slightly decreased by 4\%. In 2014 EU exports to the GCC amounted to $€ 96.784$ billion with imports from the GCC amounting to $€ 51.371$ billion $^{59}$.

Table 2: EU- GCC trade in goods.

\begin{tabular}{|l|l|l|l|l|l|}
\hline Period & $\begin{array}{l}\text { Import } \\
\left(\begin{array}{l}\text { bln. } \\
\text { euros) }\end{array}\right.\end{array}$ & $\begin{array}{l}\text { Share in } \\
\text { Extra- } \\
\text { EU }\end{array}$ & $\begin{array}{l}\text { Exports } \\
\left(\begin{array}{l}\text { bln. } \\
\text { euros) }\end{array}\right.\end{array}$ & $\begin{array}{l}\text { Share in } \\
\text { Extra- } \\
\text { EU }\end{array}$ & $\begin{array}{l}\text { Total } \\
\text { trade }\end{array}$ \\
\hline 2004 & 25.592 & 2.5 & 41,386 & 4,4 & 66,979 \\
\hline 2005 & 37.730 & 3,2 & 50,756 & 4,8 & 88.486 \\
\hline 2006 & 35.936 & 2,6 & 54,624 & 4,7 & 90,559 \\
\hline 2007 & 31.945 & 2,2 & 61,251 & 5,0 & 93,196 \\
\hline 2008 & 37.566 & 2,4 & 70,138 & 5,4 & 107,704 \\
\hline 2009 & 22.783 & 1,8 & 57,841 & 5,3 & 80,625 \\
\hline 2010 & 35.086 & 2,3 & 65,491 & 4,8 & 100,578 \\
\hline 2011 & 57.435 & 3,3 & 73,048 & 4,7 & 130,483 \\
\hline
\end{tabular}

56 ibid.

${ }^{57}$ Steffen Hertog, 'EU-GCC Relations in the Era of the Second Oil Boom', 7 $<$ http://www.cap.lmu.de/download/2007/2007 hertog.pdf $>$ accessed 21 October 2015; John Sasuya, 'The Evolving Trade and Investment Relations between East Asia and the Gulf: From Oil Dependency to Free Trade Agreements' < http://www.globaltradealert.org/sites/default/files/sasuya gta4.pdf $>$ accessed 23 October 2015.

58

$$
\text { GCC- }
$$

Trade statistics 4

http://trade.ec.europa.eu/doclib/docs/2006/september/tradoc 113482.pdf> accessed 23 October 2015.

59 ibid 5. 


\begin{tabular}{|l|l|l|l|l|l|}
\hline 2012 & 61.271 & 3,4 & 38,720 & 5,0 & 144,991 \\
\hline 2013 & 57.031 & 3,4 & 94,956 & 5,5 & 151,987 \\
\hline 2014 & 51.371 & 3,1 & 96,784 & 5,7 & 148,155 \\
\hline
\end{tabular}

The EU was the first trading partner for the GCC in 2014 covering $13.8 \%$ of its total trade, followed by China (11.9\%), Japan $(11.8 \%)$ and India $(11,1 \%)^{60}$.

Table 3: GCC trade in world.

\begin{tabular}{|c|c|c|c|c|c|c|}
\hline Partner & $\begin{array}{l}\text { Import } \\
\text { s } \\
\text { ( bln. } \\
\text { euros) }\end{array}$ & Partner & $\begin{array}{l}\text { Export } \\
\text { s } \\
\text { ( bln. } \\
\text { euros) }\end{array}$ & Partner & $\begin{array}{l}\text { Total } \\
\text { trade } \\
\text { ( bln. } \\
\text { euros) }\end{array}$ & $\begin{array}{l}\text { Share } \\
\text { in } \\
\text { Worl } \\
\text { d } \\
\end{array}$ \\
\hline EU28 & 93,201 & Japan & $\begin{array}{l}107,73 \\
4\end{array}$ & EU28 & $\begin{array}{l}144,37 \\
2\end{array}$ & 13,9 \\
\hline China & 50,113 & China & 75,621 & Japan & $\begin{array}{l}126,91 \\
1\end{array}$ & 12,2 \\
\hline USA & 43,278 & $\begin{array}{l}\text { South } \\
\text { Korea }\end{array}$ & 74,707 & China & $\begin{array}{l}125,73 \\
4\end{array}$ & 12,1 \\
\hline India & 41,430 & India & 74,211 & India & $\begin{array}{l}115,64 \\
1\end{array}$ & 11,1 \\
\hline Japan & 19,177 & EU28 & 51,171 & USA & 91,359 & 8,8 \\
\hline $\begin{array}{l}\text { South } \\
\text { Korea }\end{array}$ & 15,003 & USA & 48,081 & $\begin{array}{l}\text { South } \\
\text { Korea }\end{array}$ & 89,710 & 8,6 \\
\hline Turkey & 7,873 & $\begin{array}{l}\text { Singapor } \\
\mathrm{e}\end{array}$ & 29,845 & $\begin{array}{l}\text { Singapor } \\
\mathrm{e}\end{array}$ & 36,670 & 3,5 \\
\hline Singapore & 6,826 & Thailand & 23,185 & Thailand & 29,638 & 2,8 \\
\hline Thailand & 6,453 & Iran & 21,896 & Iran & 24,557 & 2,4 \\
\hline $\begin{array}{l}\text { Switzerlan } \\
\text { d }\end{array}$ & 6,399 & Pakistan & 12,310 & Pakistan & 15,444 & 1,5 \\
\hline
\end{tabular}

EU exports to the Gulf Cooperation Council are diverse but focused on manufactured products $(83.2 \%)$ such as power generation plants, railway locomotives and aircraft as well as electrical machinery and mechanical appliances. Machinery and transport equipment (47.9\%) and chemicals $(11.8 \%)$ were the main categories of products exported in 2014 and transport materials (which make up 49.9\%) for example, power generation plants, railway locomotives and aircraft as well as electrical machinery and mechanical appliances. EU imports from the GCC consist primarily of fuels and derivatives which made up $73.4 \%$ of total EU imports from the region in $2014^{61}$.

\section{Free Trade Agreement negotiations}

Trade and economic interests of neither the EU nor the GCC require joint action to enhance their mutual economic relations. The GCC States

\footnotetext{
60 ibid 9.

61 ibid 7.
} 
possess huge oil reserves, which are crucial for the EU and the entire world. In addition, the GCC States are developing countries that are in need of the technology, experience, and various products from the EU. Thus, this situation requires that both sides strengthen their efforts to increase trade between themselves and eliminate all trade barriers ${ }^{62}$. Therefore, Article 11 of the CA provides that the objective is to encourage, develop and diversify trade between the two contracting parties to the highest possible level, and that the two sides will initiate negotiations leading to an agreement on expanding trade according to the provisions of the Joint Declaration attached to this Agreement, and that, pending the conclusion of such trade agreement, the two contracting parties would implement the MFN principle. This document clarifies that the objective of the Free Trade Agreement is to expand trade through taking appropriate measures for improving the access of the products of either party to the other party's markets and liberalizing bilateral trade. The political decision by the Joint Council indicated that the objective of those negotiations was to conclude a Free Trade Agreement.

Negotiations were initiated in 1991, but were not conducted in a smooth manner due to certain difficulties which existed between the negotiating Parties. Following the establishment of the GCC Customs Union and unification of tariffs, the negotiations were intensified and many rounds of talks conducted in which many topics were finalized and some points remained which needed more discussion ${ }^{63}$. Both negotiating Parties expected that the establishment of the free trade area will boost inter-regional trade cooperation and the influx of investments and will lead to better conditions in the access for goods to the Common Market ${ }^{64}$. The EU has two main aims in free trade area negotiations: 1) to ensure a stable energy supply at acceptable prices and 2) to have better access for the European products to the Gulf markets. The GCC States are interested in access to the EU Common Market and trade concessions. In 2008, due to the absence of any progress in the negotiations, the GCC unilaterally suspended negotiations talks, but approved the EU demand to continue consultations between them, until a common position for resuming negotiations is achieved. It is agreed that five main factors have the negative influence on this situation: strong opposition from the European petrochemical producers'; the EU high carbon taxes; the GCC delays in the establishment of the customs union; the human rights clause which is going to be an essential part of the future agreement and export duties and the ability of the EU companies to hold major stakes in the GCC companies ${ }^{65}$. On the GCC side, Saudi Arabia refused to stop subsidising its

\footnotetext{
${ }^{62}$ Cono Giardullo, 'The Gulf Cooperation Council as a New Regional Power: Time for the EU to Propose a $\quad$ Strategic $\quad$ Partnership' 14 $<$ http://www.cris.unu.edu/fileadmin/workingpapers/BRIGG papers/BRIGG 2012 3.pdf $>$ accessed 23 October 2015.

${ }^{63}$ Rym Ayadi, S. Gadi, 'Trade and Investment Cooperation between the EU and the Gulf Cooperation Council: Current trends and future prospects' $2<$ http://www.iai.it/sites/default/files/Sharaka C 03.pdf > accessed 25 October 2015.

${ }^{64}$ Saleh Kawach, 'Massive GCC Trade Imbalance at the heart of Failed FTA with the EU' $<$ http://www.bilaterals.org/article.php3?id article=14165> accessed 25 October 2015.

65 Valentina Kostadianova, 'What is the Status of the EU-GCC Relationship?' GRC Gulf Papers $3<$ http://eu-gcc.kcorp.net/common/publicationfile/29.pdf >; George Carey, W. Mohadi, 'GCC Members Suspend Free Trade Talks with Europe, GCC Members Suspend Free Trade Talks with Europe' < http://www.bilaterals.org/?gcc-members-suspend-freetrade\&lang $=$ en $>$; Christian Koch, 'Constructing a viable EU-GCC partnership'
} 
energy industry and other the GCC Member States decided to maintain a different price of gas export, non-transparent public procurements national laws and entry barriers to foreign investors in the services sector ${ }^{66}$. On the EU side, the petrochemicals industry is against trade liberalisation, arguing that the GCC's double pricing policy is an implicit subsidy which will allow dumped imports to enter into the EU Common Market ${ }^{67}$.

\section{Energy Issues}

Today, energy is one of the main issues in bilateral relations between the EU and the GCC. Article 6 of the CA states, that " in the field of energy, Contracting Parties shall strive to encourage and facilitate: 1) cooperation in the two regions by energy undertakings, $[\ldots] ; 2$ ) joint analyses of trade between the two regions in crude oil, gas and petroleum products and its industrial aspects with a view to considering ways and means of improving their trade exchanges; 3 ) exchanges of views and information on matters relating to energy in general and respective energy policies, without prejudice to the Parties' international obligations; 4) training and 5) studies, notably on new and renewable sources of energy" ${ }^{\prime 68}$.

According to the GCC "A Statistical Glance" published in 2014, the GCC Member States possess 497,1 billion barrels of crude oil reserves, which is $43 \%$ of the world oil reserves ${ }^{69}$ and 42,221 billion standard cu $\mathrm{m}$ of natural gas reserves, which is $21 \%$ of the world gas reserves ${ }^{70}$. Currently, the energy flows between these two regions are mainly focused on petroleum and gas. The OPEC 2015 report underlines that in 2014 Kuwait exported to Europe $296 \mathrm{mln} \mathrm{b} / \mathrm{d}$ of petroleum, Saudi Arabia- $113 \mathrm{mln} \mathrm{b} / \mathrm{d}$ and United Arab

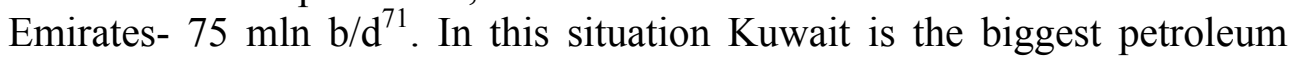
exporter to the European market. In the case of natural gas export, in 2014 Qatar exported to Europe 122,628.3 mln cu m, United Arab Emirates$15,301.6 \mathrm{mln}$. cu $\mathrm{m}$ and Oman $10,830.0 \mathrm{mln} \mathrm{cu} \mathrm{m}^{72}$. In this situation, Qatar is the biggest natural gas exporter to the European market.

To enhance cooperation in this area, the EU-GCC Joint Action Programme also contains provisions related to energy issues, which focus on: 1) exchange of views on the oil and gas market; 2) exchange of information and experiences on policies, frameworks, best practices and techniques in the field of energy; 3 ) cooperation in the field of energy equipment, machinery and spare parts manufacturing especially those used in the oil and gas

\footnotetext{
$10<$ http://eprints.lse.ac.uk/55282/1/Constructing-a-viable-U-GCC-relationship.pdf $>$ accessed 27 October 2015.

${ }^{66}$ Ayadi, Gadi (n 63) 2.

${ }^{67}$ ibid.

${ }^{68}$ Art. 6 of CA.

${ }^{69}$ The Cooperation Council for the Arab States of the Gulf- Secretariat General, 'A Statistical Glance', Vol. $\quad 4, \quad 18 \quad<$ http://sites.gcc-sg.org/DLibrary/indexeng.php?action $=$ ShowOne\&BID $=633>$ accessed 27 October 2015.

${ }^{70}$ ibid 20.

${ }^{71}$ OPEC, $\quad$ Annual Statistical Bulletin, 50-51, $<$ http://www.opec.org/opec web/static files project/media/downloads/publications/ASB20 15.pdf.> accessed 27 November 2015.

$\overline{72}$ ibid 100 .
} 
industry; 4) cooperation in the field of clean and renewable energy technologies; 5) cooperation in the field of energy efficiency policy and measures and 6) cooperation in the field of solar energy technologies and policy framework. However, special attention is devoted to cooperation in the field of clean and renewable energy technologies. As a consequence of this attitude, the EU and the GCC established in 2013 European Union and GCC network for clean energy "to facilitate this relationship and also to create a means and a practically useful tool for developing tangible cooperation activities among various actors in the sector, across the EU and the GCC. The network, therefore, aims to respond to the common interests of various actors in the field of clean energy",73.

\section{CONCLUSIONS}

The Gulf Cooperation Council is an international governmental organisation consisting of six Gulf countries: Bahrain, Kuwait, Oman, Qatar, Saudi Arabia and the United Arab Emirates, which was created in May 1981. Its main objectives are to enhance coordination, integration and interconnection among its Member States in many areas including the economy, politics, security, energy, industry, agriculture, health, education and culture. Despite a small population of just over 47 million inhabitants, the EU was the largest trading partner for the GCC in 2014 covering $13.8 \%$ of its total trade and the EU-GCC total trade in goods in 2014 amounted to around $€ 148$ billion. The GCC Member States possess almost half of global oil reserves and about $15 \%$ of natural gas reserves, which is why the GCC accounts for $25 \%$ of the EU oil imports but because of the low production costs, the importance of this region in the global supply of the energy is expected to increase in the near future. That is why we can say that economic and trade relations between the EU and the GCC are based on energy inter-dependence.

Currently, relations between the EU and the GCC are governed by a Cooperation Agreement signed in 1988 and by a Joint Action Programme agreed in 2010. The EC-GCC Cooperation Agreement is the first generation of the EC/EU international agreements which include provisions for complementing and strengthening relations by providing for the negotiations for concluding a free trade area. On the basis of the provisions of Article 11 both Parties are committed to negotiations towards a Free Trade Agreement which were initiated in 1990 but in 2008 were suspended by the GCC. The main reason for that situation was the feeling on the GCC side that they were being asked to make concessions without any reciprocity. Since 2008, no official rounds of negotiation talks have taken place; however, informal dialogues are ongoing and cover: market access for goods, services and public procurement; common rules and disciplines for intellectual property rights; competition; dispute settlement; rules of origin; human rights; illegal immigration and terrorism. The free trade area will not only improve economic relations but also will: 1) strengthen commercial and economic relations through trade liberalisation and will reinforce cooperation in related

\footnotetext{
${ }^{73}$ EU-GCC Clean Energy Network, $<\underline{\text { http://eeas.europa.eu/delegations/gulf countries/eu projects and programs/energy/index }}$ en.htm.> accessed 27 November 2015.
} 
areas; 2) simplify requirements and procedures related to imports and exports, based on international standards; 3 ) provide for the progressive and reciprocal liberalisation of trade in services; 4) include liberalisation of public procurement aimed at ensuring comparable and effective access to the Parties' procurement markets based on the principles of non-discrimination and national treatment; 5) seek to effectively and adequately protect and enforce intellectual, industrial and commercial property rights in accordance with the international standards and finally include coverage related to customs and administrative cooperation, standardisation and conformity assessment, competition, current payments and capital movements.

The EU and the GCC free trade area will set an important precedent of region-to-region cooperation and will offer a chance to: foster long-term stability in the region; support the path of development chosen by the GCC countries through intensive economic cooperation, investment and other related areas; assure the stable supply of oil and gas at reasonable prices and reposition itself in the Gulf countries, reflecting the strategic importance of the Gulf region.

To sum up, the Free Trade Agreement negotiations should be resumed and concluded as soon as possible.

\section{References}

Ayadi Rym, S. Gadi, 'Trade and Investment Cooperation between the EU and the Gulf Cooperation Council: Current trends and future prospects' $<\mathrm{http} / /$ www.iai.it/sites/default/files/Sharaka_C_03.pdf $>$.

Bhala Raj, International Trade Law: Interdisciplinary Theory and Practice (LexisNexis, New York 2008).

Carey George, W. Mohadi, 'GCC Members Suspend Free Trade Talks with Europe, GCC Members Suspend Free Trade Talks with Europe' < http://www.bilaterals.org/?gcc-members-suspend-free-trade\&lang=en>.

Echagüe Ana, 'The European Union and the Gulf Cooperation Council < http://fride.org/download/WP39_EU_Persian_Gulf_EN_may07.pdf $>$.

Giardullo Cono, 'The Gulf Cooperation Council as a New Regional Power: Time for the EU to Propose a Strategic Partnership', $<$ http://www.cris.unu.edu/fileadmin/workingpapers/BRIGG_papers/BRIGG _2012_-_3.pdf>.

Gürler Oker, 'Role and Function of regional Blocs and Arrangements in the Formation of the Islamic Common Market' (2000) 21(4) Journal of Economic Cooperation.

Hertog Steffen, 'EU-GCC Relations in the Era of the Second Oil Boom' $<$ http://www.cap.lmu.de/download/2007/2007_hertog.pdf $>$

Kawach Saleh, 'Massive GCC Trade Imbalance at the heart of Failed FTA with the EU' <http://www.bilaterals.org/article.php3?id_article=14165>.

Khader Bichara, 'EU, GCC and the Arab Spring: time for a strategic partnership?' <http://acimedit.net/wp-content/uploads/2013/04/EU-GCC- 
AND-THE-ARAB-SPRING-TIME-FOR-A-STRATEGIC-

PARTNERSHIP1>.

Koch Christian, 'Constructing a viable EU-GCC partnership' $<$ http://eprints.lse.ac.uk/55282/1/Constructing-a-viable-U-GCCrelationship.pdf $>$.

Kostadianova Valentina, 'What is the Status of the EU-GCC Relationship?' GRC Gulf Papers < http://eugcc.kcorp.net/common/publicationfile/29.pdf>.

Patrick Neil, 'The GCC: Gulf state integration or leadership cooperation?' $<$ http://eprints.lse.ac.uk/55660/>

Puig Villalta Gonzalo, B. Al.-Haddab, 'The Constitutionalisation of Free Trade in the Gulf Cooperation Council' (2011) 25 Arab Law Quarterly.

Sasuya John, 'The Evolving Trade and Investment Relations between East Asia and the Gulf: From Oil Dependency to Free Trade Agreements' < http://www.globaltradealert.org/sites/default/files/sasuya_gta4.pdf $>$.

Trulsson Asa, 'The EU's interregional relationship with the GCC- an assessment of the current cooperation $<$ https://ba.linkedin.com/pub/\%C3\%A5sa-trulsson/33/a08/ab8>. 